Available online at: http://proceeding.rsfpress.com/index.php/bemss/index

Proceeding on Business, Economy, Management and Social Studies towards Sustainable Economy (BEMSS)

Volume 1 Number 1 (2020): 17-24

\title{
The Mapping of Business Processes From Community Solid Waste to Waste Banks Using The Gonigoni Application
}

\author{
Muhammad Baqir Alhaddar', Kristina Sisilia' \\ Department of Business Administration, Telkom University, Bandung, Indonesia \\ ${ }^{1}$ Email address: bagirelhaddar23@gmail.com; ${ }^{2}$ Email address: kristina@telkomuniversity.ac.id
}

\begin{abstract}
GoniGoni is one of the platforms that manage and connect local waste banks and the community in Bandung, Indonesia. Initially, GoniGoni was established to provide solutions to the problem of garbage around the Telkom campus. Currently, GoniGoni will serve outside the area of Bandung. GoniGoni aims to educate the market that waste disposal can lead to passive income by using this application. Having a business process can give benefit an organization by enabling it to optimize its operation. However, GoniGoni hasn't mapped its business process, yet. This study aims to map business processes in GoniGoni startup. The information required is obtained through interviews with the founder and team of GoniGoni, who are considered to understand the business best (purposive sampling). The business processes of waste banks are divided into five sub-processes, namely application registration, one-time request, subscription registration, waste collection operation, and payment.
\end{abstract}

Keywords: Business Process, Efficiency, Waste Bank, Community.

This is an open access article under the CC-BY-NC license.

\section{INTRODUCTION}

Every business person attempts to manage their business activities and processes to proceed as planned and be able to create a win-win solution that can provide benefits for each party involved. According to Martina (2019), Supply Chain Management (SCM) plays an essential role in the sustainability of business processes. SCM has several functions, including Planning, Management, Human Resources (HR), Instruction, and Control. SCM assists in providing benefits for each party involved in the business.

Hammer and Champy in Widayanto (2017) define business processes as a collection of activities that require one or more inputs and produce useful or valuable outputs to customers. All companies certainly have their business processes, including GoniGoni. GoniGoni carries out several business processes such as collecting waste from the community, withdrawing money from waste savings, to guiding work partners such as the community, scavengers, and waste bank workers. All business processes manage to achieve the same goal, namely, environmental stewardship and profit. A company generates profit from the difference between revenue and the cost of goods sold (COGS). In this regard, GoniGoni can increase profit through the increase in revenue, by encouraging the customers to be more environmentally conscious regarding waste disposal, eventually leading to an 
Proceeding on Business, Economy, Management and Social Studies towards Sustainable Economy (BEMSS)), Vol. 1(1), 17-24

The Mapping of Business Processes From Community Solid Waste to Waste Banks Using The Gonigoni Application Muhammad Baqir Alhaddar, Kristina Sisilia

increase in the users of the GoniGoni application. The company can also increase profit through COGS, the success of which depends on the capability of the company regarding cost-efficiency. Process efficiency can be implemented in various ways, one of which is through business process improvement. Streamlining business processes will reduce costs and thus increase profit.

According to Hartono (2017), business process improvement (BPI) is a planning methodology in business processes or employee skills that can be improved to encourage more efficient and effective workflows and procedures for overall business growth. It aims to eliminate mistakes as well as increase the competitive advantage of the company by improving business processes, in addition to meeting customer demands and business goals more effectively. Nevertheless, before analyzing the efficiency of business processes, it is necessary to map the business processes to describe a complete process, allowing all company members from different levels of position to increase the process flow (Putri, 2018). This study aims to map business processes in GoniGoni startup to facilitate GoniGoni in making future decisions, such as conducting business process efficiency.

This study only maps business processes in GoniGoni and does not analyze the efficiency and effectiveness of the business processes. Therefore, the result of this study is a map of business processes of waste disposal by the community to waste banks through the GoniGoni application. The stages of business processes can be analyzed afterward using this result.

\section{LITERATURE REVIEW}

\subsection{Theory of Community}

Maryani \& Nainggolan (2019), in their book, state that, according to Macionis, the community is a large number of people who interact with each other and live in the same area, relatively independent with people outside the region and having a relatively similar culture. Furthermore, in the same book, M.J. Heskovitas defines community as a group of individuals who organize and follow a particular way of life.

\subsection{Theory of Waste and Waste Bank}

Tchobanoglous in Saputro et al. (2015) defines waste as all forms of solid waste originating from human and animal activities and then discarded because it is of no use or no longer wanted. A waste bank is a place used to collect waste that has been sorted. The collected waste will then be deposited to crafters creating waste-based handicrafts or waste collectors. According to the Regulation of the Minister of Environment of the Republic of Indonesia No 13 of 2012, a waste bank is a place for sorting and collecting waste that has economic value to be recycled and reused.

\subsection{Supply Chain Management (SCM) Theory}

SCM is a concept or mechanism to increase total company productivity in the supply chain through optimization of time, location, and material quantity flow. According to Schroeder, Supply Chain Management is the planning, design, and control of the flow of information and goods throughout the supply chain, aiming to meet the present and future requirements of customers efficiently. Supply Chain Management is also known as a supply chain, a logistics network, or a supply network, namely a coordinated system consisting of organizations, human resources, activities, information, and other sources that are collectively involved in moving a product or service, both in physical and virtual form, from a supplier to customers (Arif in Supply Chain Management, 2018).

\subsection{Business Process Theory}

According to Yun Chank in Sari and Asniar (2015), business processes are a collection of structured tasks or activities that can produce certain services or products for one or many customers. Business 
processes, according to Hammer, are vital to manage existing activities and understand the relationships between these activities. Business processes are a collection of activities that accept one or more inputs and produce valuable outputs for customers (Permatasari et al., 2018).

\section{METHODOLOGY}

According to Sugiyono $(2019$, p. 2), the research method is a scientific way to obtain data with specific purposes and uses. There are four keywords to consider, namely scientific method, data, purpose, and certain uses. This study applied a descriptive qualitative approach to thoroughly and deeply describe the business processes of GoniGoni.

In this study, the social situation to be investigated is waste disposal activity by the community (actors) to the waste banks through GoniGoni (location). The unit of analysis will adjust to the approach used in the study. This study employed a descriptive qualitative approach, thus, the unit of analysis is the explanations and depictions obtained from interviews about the flow of business processes of waste disposal activity. The qualitative method in this study used a purposive sampling technique to ensure that the data obtained have a fairly high level of accuracy because the informants are considered to have the best understanding in this field.

The informants of the study are:

Table 1. Informants of the study

\begin{tabular}{|c|c|c|}
\hline NO. & NAME & ROLE \\
\hline 1. & Firza Maulana Nasution & GoniGoni's Founder \& Director \\
\hline 2. & Rayan Fahlevi Dahlan & $\begin{array}{c}\text { GoniGoni's CoFounder \& Operation Manager works on } \\
\text { GoniGoni’s daily operation in the field. }\end{array}$ \\
\hline 3. & Andi Habil Dwi Syahputra & $\begin{array}{c}\text { GoniGoni's CoFounder \&Technology Manager that works on } \\
\text { technology and development of GoniGoni's Platform. }\end{array}$ \\
\hline
\end{tabular}

In this study, the authors applied the triangulation method in testing credibility, namely checking data from various sources in various ways and at various times. By using this method, it is expected that the data in this study have a fairly high level of validity. The first and most important informant is the founder and Director of GoniGoni. Since this study focuses on an internal company, it will be easier to obtain data from the person in charge and work in the operation and technology of GoniGoni, which are the operation manager and the technology manager of GoniGoni.

\section{RESULT AND DISCUSSION}

Waste disposal is one of the leading business processes in the GoniGoni application. The business processes of solid-waste disposal are broadly divided into five sub-processes, namely application registration, one-time request, subscription registration, waste collection operation, and payment.

The first sub-process is the registration to the GoniGoni application by filling the form of registration (either by the community or the waste banks) to be the customers of the GoniGoni app. Afterward, there will be related data required to be filled in the application. These inputs will generate outputs in the form of completed registration of the associated parties as members of GoniGoni, marked by the access to the transactions of waste disposal, as presented in Figure 1. 
Proceeding on Business, Economy, Management and Social Studies towards Sustainable Economy (BEMSS)), Vol. 1(1), 17-24

The Mapping of Business Processes From Community Solid Waste to Waste Banks Using The Gonigoni Application Muhammad Baqir Alhaddar, Kristina Sisilia

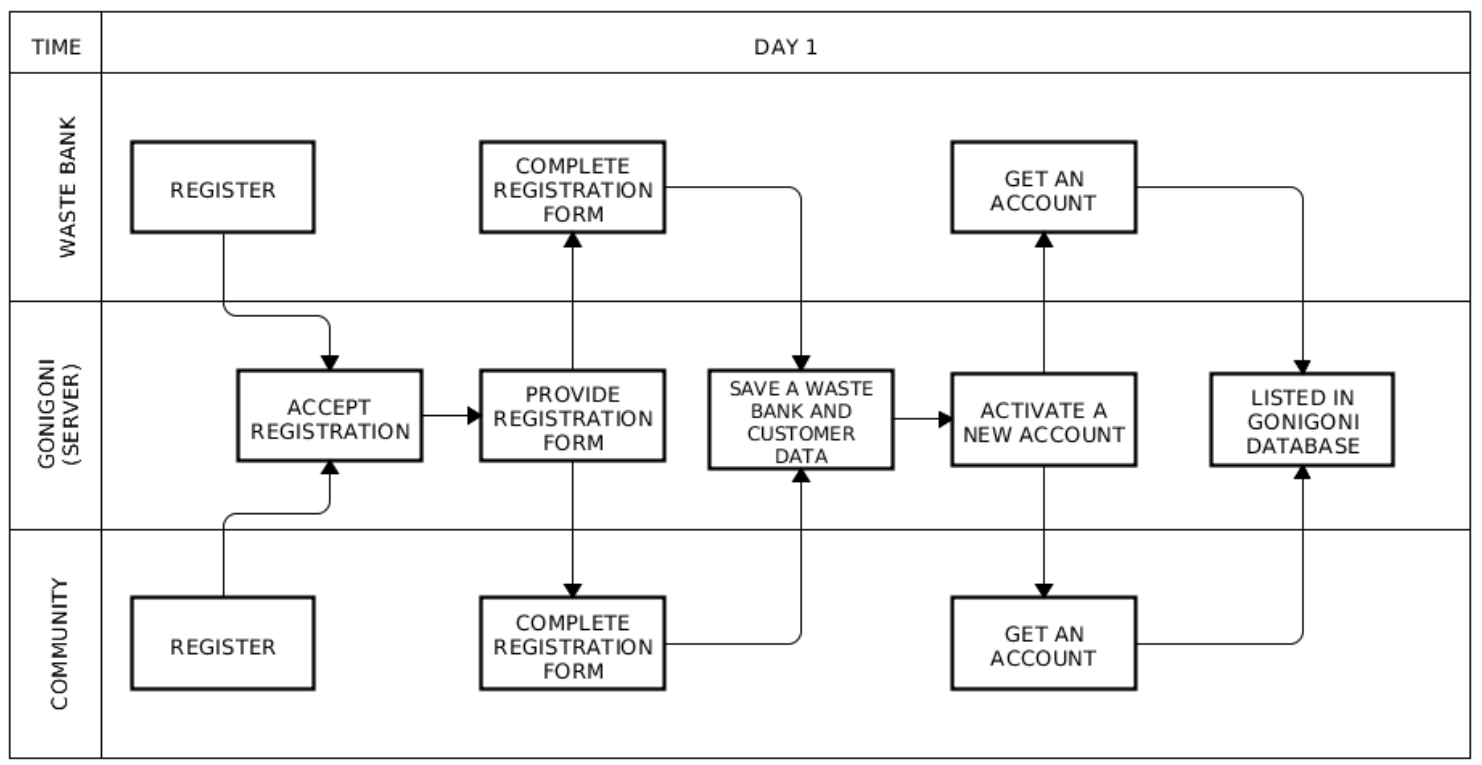

Fig 1. The Sub-Process of Registration in the GoniGoni Application

Source: Processed by authors, 2020

To register in the GoniGoni application, prospective users are merely requested to provide identification, such as e-mail, telephone number, user name, password, and address. The identification will help in future operations in the GoniGoni application. GoniGoni uses telephone number to contact the customer and address to find out the location of the waste bank and the customer when GoniGoni collects the waste. GoniGoni's activities part in figure 1 looked like a manual input activity in a conventional waste bank. GoniGoni can change it into a one-page Login window in their app rather than four clicks in figure 1.

After completing the first sub-process, the customers will proceed to the second and third sub-processes, namely determining the methods. The methods are divided into two types: a one-time request or a subscription. In a subscription, the customers only need to determine the routine pickup schedule at the beginning. In a one-time request, however, the customers need to decide the pickup schedule each time the customers will dispose of waste. The difference between the two methods is presented in Figures 2 and 3.

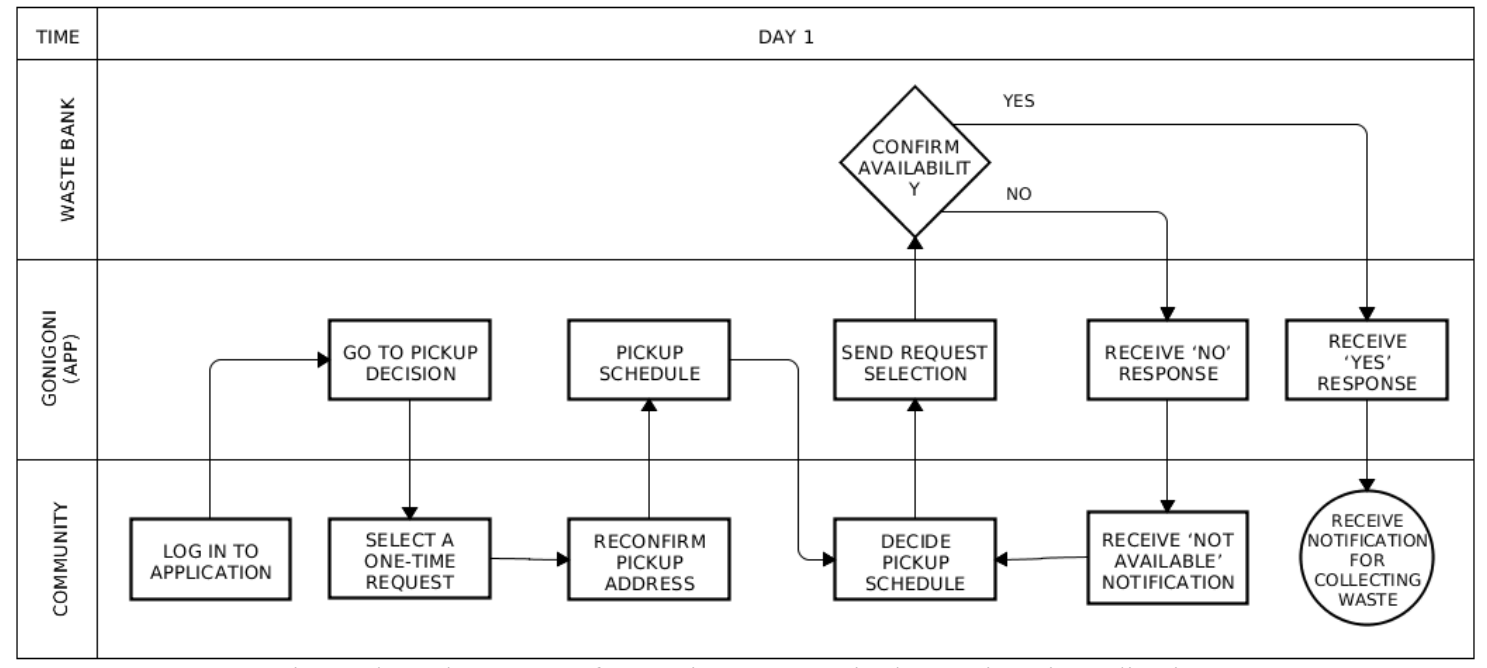

Fig 2. The Sub-Process of One-Time Request in the GoniGoni Application Source: Processed by authors, 2020 
Furthermore, the operational subscription of GoniGoni will recommend the nearest waste banks, and the customers are free to choose the desired waste bank. In a one-time request, the customers are not free to choose the waste bank. It depends on the availability of the waste bank at the predetermined time. Thus, one-time customers cannot choose the desired waste bank. GoniGoni can consider giving more flexibility to pick up waste time and the desired waste bank.

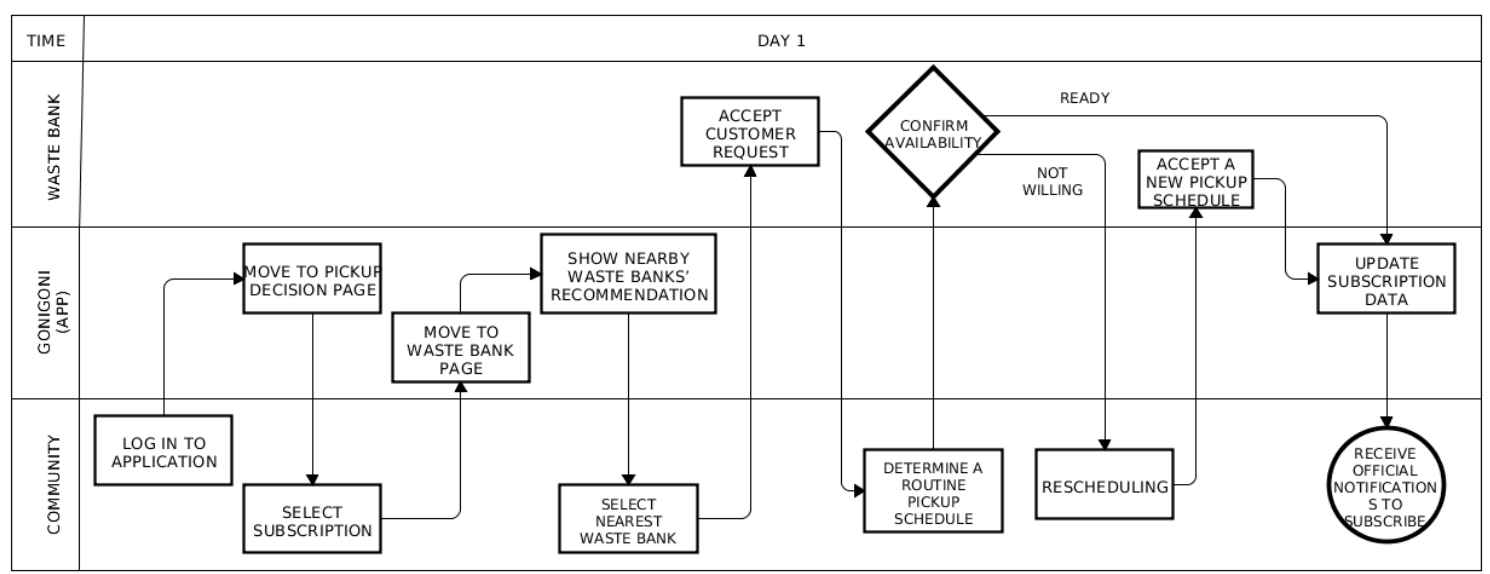

Fig 3. The Sub-Process of Subscription Registration in the GoniGoni Application Source: Processed by authors, 2020

As shown in Figure 4, the sub-process of waste collection operation starts with a pick-up notification received by the customers and ends with the waste bank transferring the overpayment to GoniGoni. The waste that has been collected will be categorized and weighed to determine the price that will be provided for the customers. The category of waste is determined by the sorting carried out by the customers. The waste that has been sorted will have a higher sales value compared to the waste that has not been sorted since the waste bank will cut the price of the waste for sorting costs.

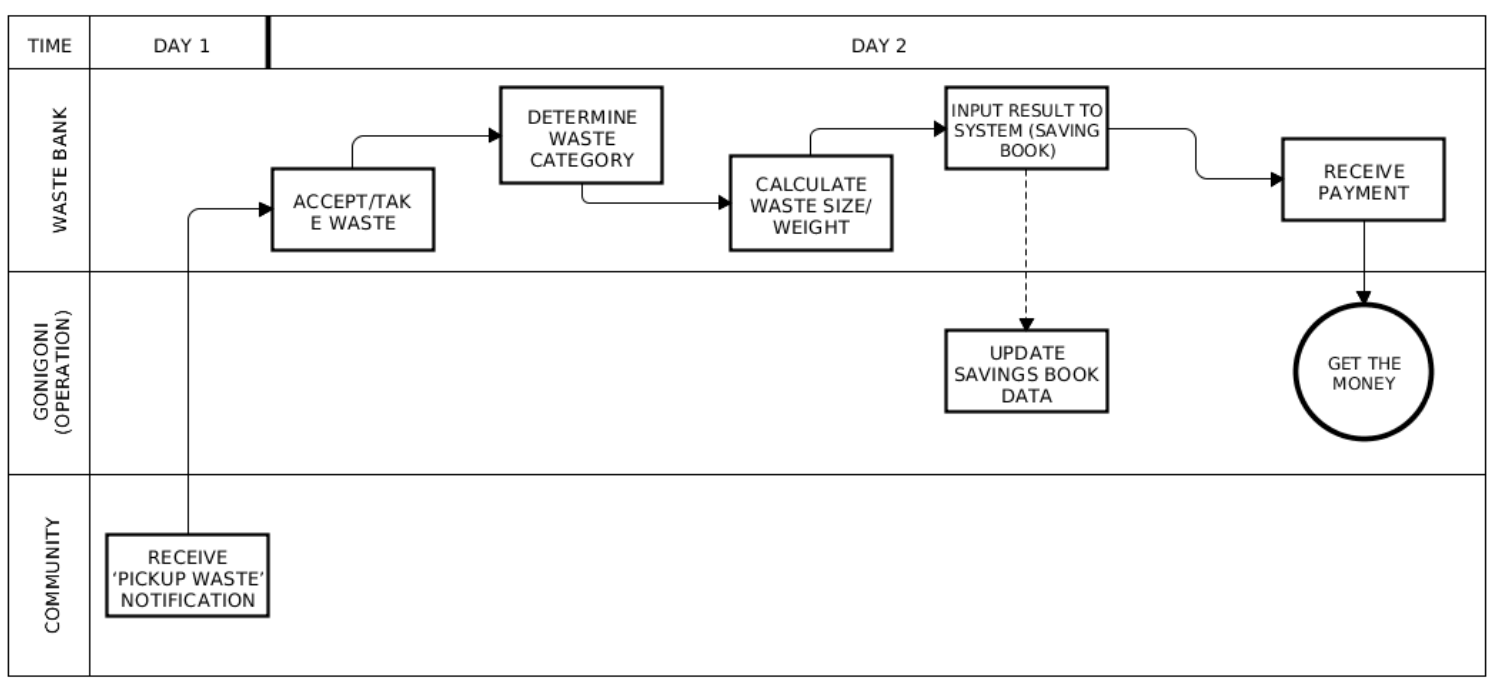

Fig 4. The Sub-Process of Waste Collection Operation

Source: Processed by authors, 2020

The last sub-process is payment. In this sub-process, the waste bank will provide the amount of money, based on the weight of the waste, to the customers. There are two methods to select, either 
Proceeding on Business, Economy, Management and Social Studies towards Sustainable Economy (BEMSS)), Vol. 1(1), 17-24

The Mapping of Business Processes From Community Solid Waste to Waste Banks Using The Gonigoni Application Muhammad Baqir Alhaddar, Kristina Sisilia

directly to the customer, immediately following the weighing or indirectly through GoniGoni. Figure 5 shows the payment method through GoniGoni. GoniGoni will deduct the payment by six percent $(6 \%)$ of the total amount. The money obtained from this deduction will be used for the system maintenance of GoniGoni. The remaining amount of the payment shall be transferred to the customers with an expected delay of one to two days since the bank transfers the payment to waste banks.

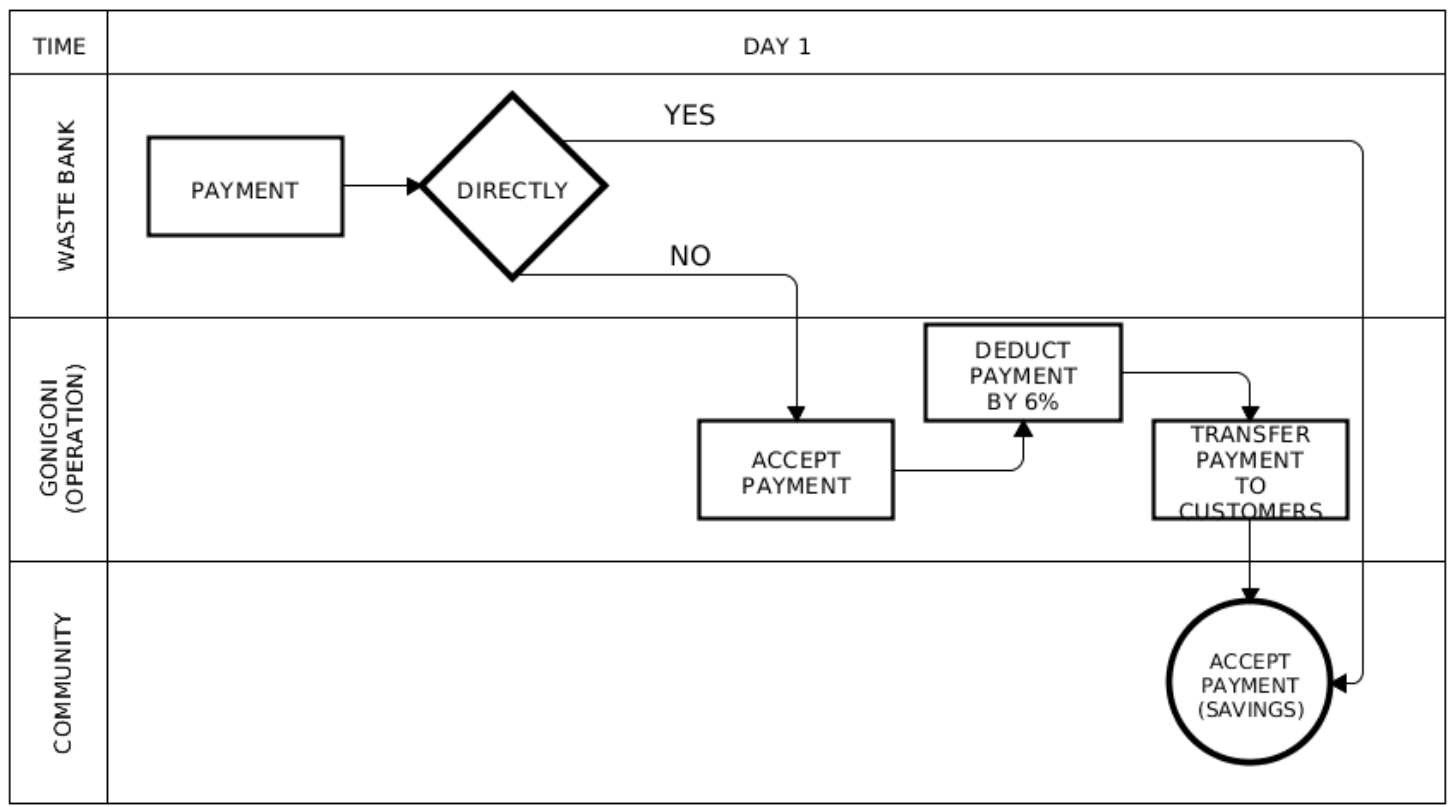

Fig 5. The Sub-Process of Payment

Source: Processed by authors, 2020

The direct method of payment results in less optimization of the GoniGoni application as a bridge between the customers and waste banks. Therefore, the payment should be processed with one method only, namely through GoniGoni. It is recommended that the payment is made through the GoniGoni platform, by educating customers who directly come to the nearest waste banks or scavengers who have an agreement with all local waste banks that use the GoniGoni platform. The payment sub-process will be, as shown in Figure 6. 


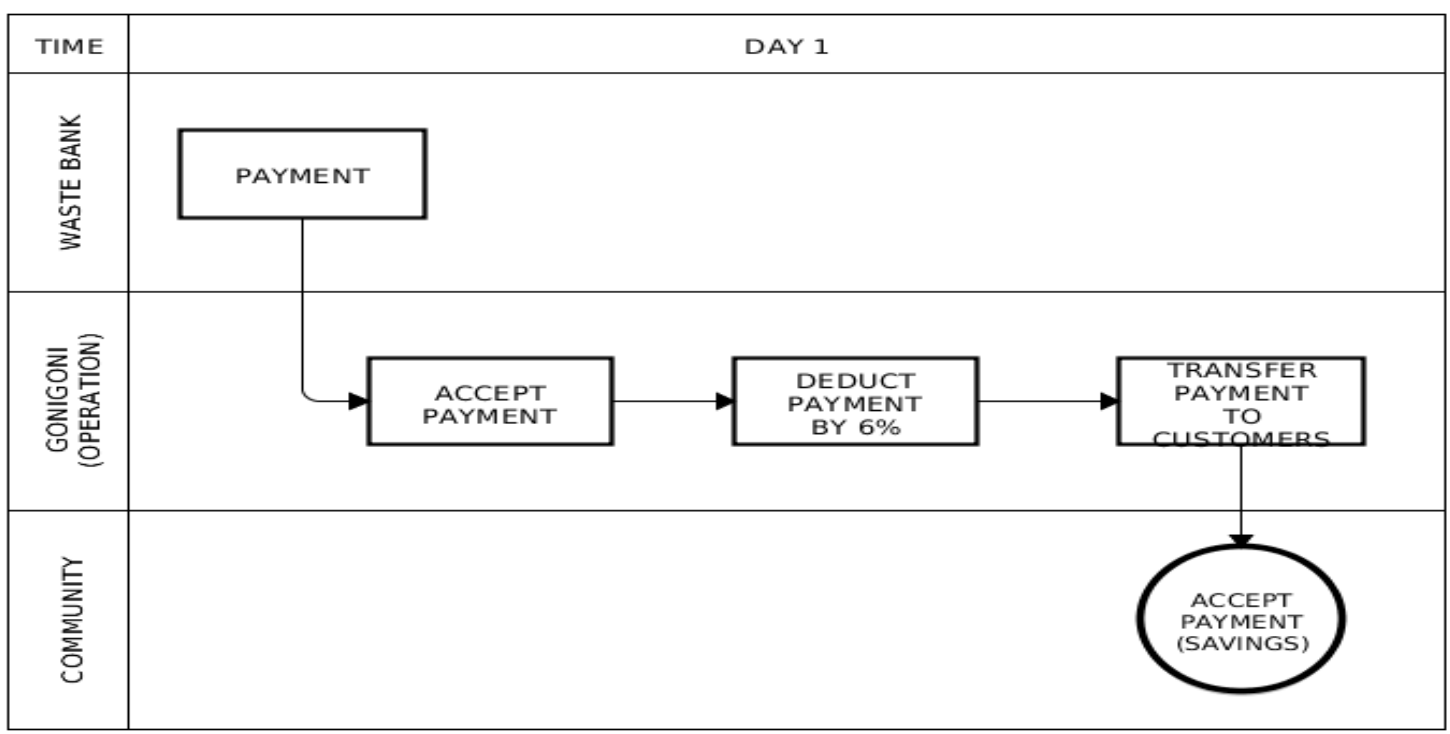

Fig 6. The Sub-Process of Payment with One Method (Suggestion for Improvement)

Thus, the digitization plan will fully be achieved since every activity in the sub-process is carried out through the GoniGoni application. Payment through the GoniGoni app will have an impact on the increase in the use of the GoniGoni application, and GoniGoni will continue to obtain its share of six percent $(6 \%)$ of each transaction from waste disposal made by customers for maintenance activities. Another option for this part is GoniGoni can offload payment system to other parties, such as fin-tech companies like OVO, Dana, Gojek, etc.

In addition to the sub-process of payment, the authors also discovered several sub-processes that need improvements in terms of customer convenience in using the application. In a one-time request sub-process, for example, waste disposal cannot be processed on the same day the request is made. The customers should be provided with this convenience, in which the waste is collected on the same day they request to avoid piling-up waste. However, this "one-day" service may be more expensive to cover the immediate operational costs. According to the authors, it is necessary to provide such service despite additional expenses, since the customers may have more options when they want to dispose of waste.

This study provides convenience for GoniGoni in making future decisions regarding optimizing their business process. This study describes the business processes in GoniGoni in detail, and the map will facilitate GoniGoni in observing both good and less optimal business processes. Therefore, improvements in the internal divisions of the company may be more accurate.

\section{CONCLUSION}

The waste disposal activity carried out by the community to the waste bank through the GoniGoni application consists of five business sub-processes, namely application registration, one-time request, subscription registration, waste collection operation, and payment.

In waste collection operation, there is an input in the form of waste from customers that will be processed by the waste bank to produce output in the form of savings from waste disposal. Overall, the business processes of waste disposal activity by the community to the waste bank through the GoniGoni application will generate output in the form of savings to the customers from waste disposal with the payment made through GoniGoni. 
Proceeding on Business, Economy, Management and Social Studies towards Sustainable Economy (BEMSS)), Vol. 1(1), 17-24

The Mapping of Business Processes From Community Solid Waste to Waste Banks Using The Gonigoni Application Muhammad Baqir Alhaddar, Kristina Sisilia

GoniGoni should be able to improve the streamlined of its business processes further to be more productive and efficient. GoniGoni also has to conduct socialization to the community about protecting the environment and sort waste. Thus the community will better understand the importance of these aspects.

\section{ACKNOWLEDGEMENT}

The authors acknowledge the involvement of a great number of parties in providing motivation and support for this study. Therefore, the authors would like to offer gratitude to Firza Maulana Nasution and his team for his permission and willingness to assist in obtaining data for this study.

\section{REFERENCES}

Arif, Muhammad. (2018). Supply Chain Management. Yogyakarta: Deepublish.

Maryani, Dedeh. \& Nainggolan, R.R.E. (2019). Pemberdayaan Masyarakat. Yogyakarta: Deepublish.

Menteri Lingkungan Hidup RI. (2012). Peraturan Menteri Lingkungan Hidup RI Nomor 13 Tahun 2012 Tentang Pedoman Pelaksana Reduce, Reuse, dan Recycle. Jakarta: KEMEN-LHK.

Permatasari, M.Y. Aknuranda, I. Setiawan, Y.N. (2018). Analisis dan Perbaikan Proses Bisnis dengan menggunakan Teknik Esia (Studi Kasus: Departemen Produksi PT XYZ). (Vol.2). Malang.

Putri, N.A. (2018). Analisis Proses Bisnis. Bandar Lampung.

Saputro, Y.E. Kismartini. Syafrudin. (2015). Pengelolaan Sampah Berbasis Masyarakat Melalui Bank Sampah. Semarang: Indonesian Journal of Conservation.

Sari, S.K. \& Asniar. (2015). Analisis Dan Pemodelan Proses Bisnis Prosedur Pelaksanaan Proyek Akhir Sebagai Alat Bantu Identifikasi Kebutuhan Sistem. (Vol.7). Bandung: Jurnal Infotel.

Sugiyono. (2019). Metode Penelitian Kuantitatif Kualitatif Dan R\&D. Bandung: Alfabeta.

\section{Bibliography From the Internet}

Martina. (2019, April). Apa Itu Supply Chain Management (SCM) Serta Pentingnya SCM Dalam Proses Bisnis. Retrieved from Ukirama: https:/ukirama.com/en/blogs/apa-itu-supply-chainmanagement-scm-serta-pentingnya-scm-dalam-proses-bisnis. (Access January 21, 2020). 